\title{
SIM1 Gene
}

National Cancer Institute

\section{Source}

National Cancer Institute. SIM1 Gene. NCI Thesaurus. Code C75505.

This gene plays a role in transcription and neurogenesis. 